\title{
Plazmacitoidni mioepiteliom tvrdog nepca: prikaz slučaja
}

\section{Plasmacytoid Myoepithelioma of the Hard Palate: Case Report}

\begin{abstract}
Zavod za oralnu medicinu i patologiju Stomatološkog fakulteta Atenskoga sveučilišta, Atena, Grčka University of Athens, School of Dentistry, Department of Oral Medicine and Pathology
\end{abstract}

\section{Sažetak}

Svrha: Mioepiteliomi su rijetke neoplazme žlijezda slinovnica, a sastoje se u cijelosti ili predominantno od stanica mioepitelnog fenotipa. Obično zahvaćaju parotidu i male žlijezde slinovnice na nepcu. Svrha rada: Opisan je slučaj plazmacitoidnog mioepitelioma tvrdog nepca. Opis slučaja i rezultati: Opisani tumor buknuo je na tvrdom nepcu 55-godišnje žene. Mikroskopskim pregledom ustanovljena je dobro ograničena neoplazma, ali ne i učahurena, a sadržavala je uglavnom plazmacitoidne stanice u labavoj fibrovaskularnoj stromi. Imunohistokemijski te su stanice reagirale s proteinom s-100, CK AE1/AE3 (slika 5 b), GFAP-om, kalponinom i CD138/sindekanom 1. Terapija se sastojala od uklanjanja cijelog tumora u lokalnoj anesteziji. Ni 14 mjeseci nakon zahvata nije bilo uočeno vraćanje novotvorine. Zaključak: Budući da se plazmacitoidni mioepiteliom rijetko pojavljuje na žlijezdama slinovnicama, njegova imunohistokemijska svojstva, liječenje i prognoza trebali bi se još detaljnije istražiti.
Uvod

Mioepiteliomi su benigne neoplazme žlijezda slinovnica i uglavnom se sastoje od stanica mioepitelnog fenotipa ili većinom od tih stanica $(1,2)$. Pojavljuju se približno kod 1,5 posto tumora žlijezda slinovnica (3) i obično zahvaćaju parotidnu žlijezdu ili male žlijezde slinovnice na nepcu $(1-4)$. Nema preferencije u dobi ili spolu, ali češće obolijevaju osobe srednjih godina $(1-4)$. Obično im se pojavljuju asimptomatske, dobro ograničene tumorske tvorbe koje rastu sporo i normalne su boje, na dodir su meke do tvrde $(2-4)$ i nisu povezane $s$ neurološkim simptomima $(3,4)$.

Mikroskopski je vidljiv jedan tip ili svi tipovi neoplastičnih mioepitelnih stanica, primjerice vretenaste, plazmacitoidne (hijaline) epiteloidne, čiste, poligonalne, bazaloidne ili onkocitne i sve su poredane jednolično prema miksoidnom, retikularnom, mikrocističnom ili kribifornom modelu rasta $(1,3,5)$. Predominantni tip stanica definira podtip tumora, premda ni tipovi stanica ni obrasci rasta ne koreliraju s kliničkim izgledom ili biološkim ponašanjem lezije (1). Vretenasti podtip stanica uobičajen je ako je zahvaćena parotidna žlijezda, a plazmacitoidni kad je riječ o malim žlijezdama slinovnicama (2). I dalje je predmet rasprave je li mioepiteliom poseban entitet ili varijanta pleomorfnog adenoma s prevagom stanica mioepitelnog fenotipa.

Uz zapise Zormpa i suradnika (6) koji su opisali 19 slučajeva plazmacitoidnog mioepitilioma tvrdog nepca, u literaturi su obrađena još tri slučaja $(7,8,9)$. U ovom tekstu opisan je još jedan slučaj plazmacitoidnog mioepitelioma tvrdog nepca.

\author{
Zaprimljen: 27. ožujka 2016. \\ Prihvaćen: 6. ožujka 2017. \\ Adresa za dopisivanje \\ Konstantinos Tosios \\ University of Athens \\ School of Dentistry \\ Department of Oral medicine and \\ Pathology \\ 2 Thivon str. Goudi \\ 11527 Athens, Greece \\ Ključne riječi \\ tumori žlijezda slinovnica; mioepiteli- \\ om; pleomorfni adenom; tvrdo nepce
}

\section{Introduction}

Myoepitheliomas are benign salivary gland neoplasms consisting entirely or predominantly of cells with myoepithelial phenotype $(1,2)$. They represent approximately $1.5 \%$ of all salivary glands tumors (3) and usually involve the parotid gland or the minor salivary glands of the palate (1-4). They show no age or gender predilection, but they are more common in middle-aged persons (1-4). They present as asymptomatic, slowly growing and well-circumscribed tumors of normal color that may be soft to hard on palpation [2-4], and are not associated with neurological symptoms $(3,4)$.

Microscopically, one or all types of neoplastic myoepithelial cells, i.e. spindle, plasmacytoid (hyaline), epithelioid, clear, polygonal, basaloid or oncocytic, may be seen, arranged in solid, myxoid, reticular, microcystic or cribiform growth patterns $(1,3,5)$. The preponderant cell type defines the tumor's subtype, although neither cell type nor growth pattern correlate with the clinical presentation or biologic behavior of the lesion (1). The spindle cells subtype is more common in the parotid gland and the plasmacytoid in the minor salivary glands of the palate (2). Whether myoepithelioma is a distinct entity or a variant of pleomorphic adenoma with a preponderance of cells with myoepithelial phenotype is disputable.

Since the review of the English literature by Zormpa et al (6) in 2011, where 19 cases of plasmacytoid myoepithelioma of the hard palate were included, three more cases have been published $[7,8,9]$. An additional case of plasmacytoid myoepithelioma of the hard palate is described. 


\section{Prikaz slučaja}

Žena od 55 godina upućena je na dijagnosticiranje i terapiju bezbolne otekline na tvrdom nepcu koja se postupno povećavala tijekom nekoliko mjeseci. U osobnoj i obiteljskoj anamnezi nije bilo takve bolesti.

Oralnim pregledom otkrivena je okrugla, dobro ograničena masa prekrivena normalnom sluznicom na desnom stražnjem dijelu nepca, između pretkutnjaka i središnje linije (slika 1.). Bila je velika oko $2,5 \times 2 \times 1,5$ centimetara, mogla se stisnuti i bila je mekana na palpaciju. Prvi kutnjak nije reagirao na testiranje pulpe, ali ostali susjedni zubi bili su vitalni. Nije

\section{Case report}

A 55 year-old woman was referred for diagnosis and management of a painless swelling on the hard palate that had gradually enlarged during the last few months. Family and past medical histories were non-contributory.

Oral examination revealed a round, well-circumscribed mass covered by normal mucosa on the right posterior hard palate, between the premolar teeth and the midline (Figure 1). It measured approximately $2.5 \times 2 \times 1.5 \mathrm{~cm}$ and was $\mathrm{com}-$ pressible and non-tender on palpation. The first molar tooth did not react to pulp testing, but adjacent teeth were vital.
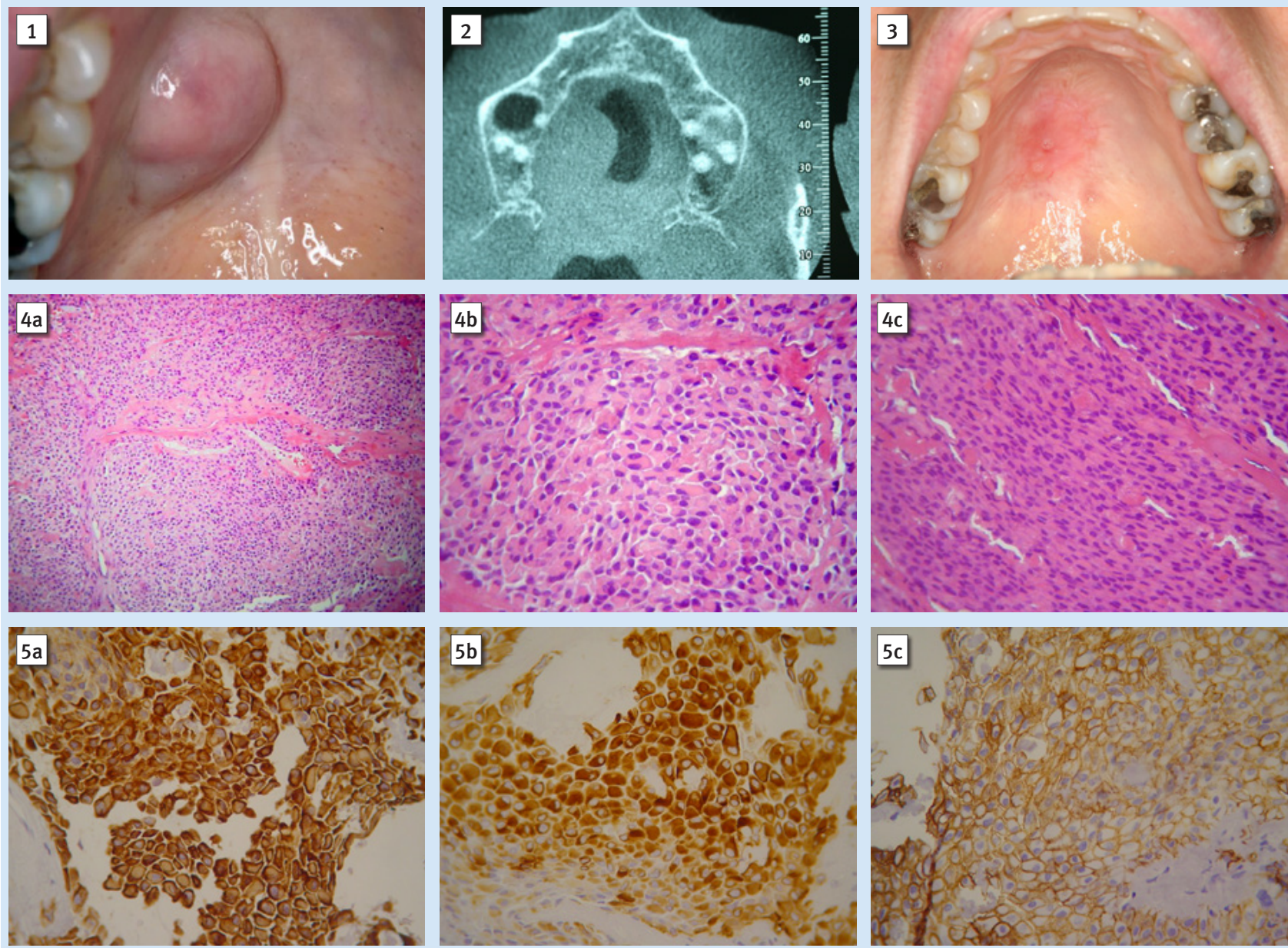

Slika 1. Oralni pregled - okrugla, dobro ograničena masa prekrivena normalnom sluznicom na stražnjem desnom dijelu tvrdog nepca, između pretkutnjaka i središnje linije

Figure 1 Oral examination. A round, well-circumscribed mass covered by normal mucosa on the right posterior hard palate, between the premolar teeth and the midline.

Slika 2. Zubni sken - prosvjetljenje mase koja ne zahvaća maksilarnu kortikalnu kost; cistična lezija vidljiva je apikalno od prvoga kutnjaka (zvjezdica)

Figure 2 Dental scan. The hypodense mass does not involve the maxillary cortical bone. A cystic lesion is seen apically to the first molar tooth (asterisk).

Slika 3. Kontrola - poslijeoperacijsko cijeljenje 14 mjeseci nakon terapije

Figure 3 Follow up. Postsurgical healing 14 months after treatment.

Slika 4. Mikroskopska obilježja - (a) solitarni čvorovi neoplastičnih stanica uklopljenih labavo u vaskularnu stromu vezivnoga tkiva (hematoksilin-eozinsko bojenje, povećanje $200 \mathrm{x}$ ); (b) plazmacitoidne i (c) vretenaste mioepitelijalne stanice (hematoksilin-eozinsko bojenje, povećanje $400 \mathrm{x}$ ).

Figure 4 Microscopic features. (a) Solid nests of neoplastic epithelial cells embedded in a loose vascular connective tissue stroma (hematoxylin and eosin stain, original magnification x200). (b) Plasmacytoid and (c) spindle-shaped myoepithelial cells (hematoxylin and eosin stain, original magnification $\times 400$ ).

Slika 5. Imunohistokemijska obilježja plazmacitoidnih stanica - (a) intenzivno pozitivna reakcija u citoplazmi na protein S-100 i (b) na GFAP (c); snažna pozitivna reakcija na membrani za CD138/sindekan-1 (originalno povećanje $400 \mathrm{x}$ )

Figure 5 Immunohistochemical features of plasmacytoid cells. (a) An intense cytoplasmic positivity for S-100 protein and (b) GFAP. (c) Strong, membranous positivity for CD138/Syndecan-1 (original magnification $\times 400$ ). 
bilo regionalne limfadenopatije. Panoramski radiogram i zubni sken pokazali su masu manje gustoće od kosti koja nije zahvaćala maksilarnu kortikalnu kost, te je identificirana cistična lezija apikalno uz prvi kutnjak (slika 2.). Inicijalna klinička dijagnoza bila je tumor žlijezda slinovnica, pa je obavljena incizijska biopsija na temelju koje je postavljena dijagnoza u suglasju s pleoformnim adenomom. Naposljetku je u lokalnoj anesteziji obavljena ekscizija cijelog tumora. Poslijeoperacijsko cijeljenje bilo je bez poteškoća te ni 14 mjeseci nakon terapije nije uočena ponovna pojava novotvorine (slika 3.).

Mikroskopskim pregledom rezova od $5 \mu \mathrm{m}$ tkiva fiksiranih u formalinu (uronjenih u parafin), uočena je dobro ograničena tvorba bez čahure koja se sastojala od slojeva i nakupina neoplastičnih epitelnih stanica uklopljenih u labavu fibrovaskularnu stromu (slika 4. a). Većina stanica imala je plazmacitoidna (hijalina) milohioidna obilježja, primjerice obilnu eozinofilnu neoplazmu i ovalnu, blago zgusnutu, ekscentričnu jezgru (slika 4. b). Uočena je i mala grupa vretenastih stanica s gustim jezgrama (slika 4. c) te minimalni stanični i nuklearni pleomorfizam te bez netipičnih mitoza. Zabilježene su i rijetke strukture odvodnih kanala koje su činile samo dva posto ukupnog parenhima, a acinusna diferencijacija je nedostajala. Na mjestu incizijske biopsije nađeni su krvarenje, upala i pseudoepitelematozna hiperplazija pokrovnog dijela parenhimatozne sluznice. Provedena je imunohistokemijska analiza standardnim tehnikama avidin-biotinske peroksidase nakon predtretmana visokotemperaturnim citratnim puferom i protutijelima na protein S-100 (poliklonal, $1: 100$, Dako, Glostrup, Danska), citokeratin (CK AE1/ AE3, $1: 50$, Dako, Glostrup, Danska), kiseli protein glial fibrilar (GFAP, 6F2, 1 : 100, Dako, Glostrup, Daska), kalponin (CALP, 1Q50, Dako, Glostrup, Danska), a-SMA (HHF35, 1:50, Dako, Glostrup, Dnska), p63 (VS 38c, 1:100, Dako, Glostrup, Danska), CD138/sindekan-1 (B-A38, 1 : 50, Abcam, Cambridge, MA, SAD) i Ki 67 (Mib1, 1: 500, Dako, Glostrup, Danska).

Plazmacitoidne i vretenaste stanice pokazivale su intenzivnu citoplazmatsku pozitivnu obojenost na protein S-100 (slika 5. a), a plazmacitoidne difuznu citoplazmatsku pozitivnost na CK AE1/AE3, GFAP (slika 5. b) i kalponin, razbacanu pozitivnu citoplazmatsku reakciju na a-SMA i p63, te jaku, membransku pozitivnu reakciju na CD138/Sindekan-1 (slika 5. c). Proliferacijski indeks Ki 67 bio je manji $(<)$ od jedan posto. Na temelju tih podataka postavljena je dijagnoza plazmacitoidnog mioepitelioma.

\section{Rasprava}

U prikazanom slučaju opisana su klinička, mikroskopska i imunohistokemijska obilježja koja odgovaraju plazmacitoidnom mioepiteliomu. Na panoramskom radiogramu i zubnim skenovima nisu bili uočeni znakovi erozije obližnje kosti koji se obično nalaze u slučaju benignih tumora žlijezda slinovnica, uključujući i plazmacitoidni mioepiteliom (7). Mikroskopski se razlikovanje od uobičajenoga pleomorfnog adenoma temelji na ograničenoj diferencijaciji odvodnih kanala koja je u ovom slučaju bila manja od dva 2 posto i na nedostatku hondroidne ili osteoidne strome te na prevladavanju
There was no regional lymphadenopathy. Panoramic radiograph and dental scan showed a hypodense mass that did not involve the maxillary cortical bone, and identified a cystic lesion apically to the first molar tooth (Figure 2). With the clinical diagnosis of a salivary gland tumor, an incisional biopsy was done that rendered the diagnosis "consistent with a pleomorphic adenoma". Consequently, total excision of the tumor under local anesthesia was performed. Postsurgical healing was uneventful and no recurrence has been recorded 14 months after treatment (Figure 3).

Microscopic examination of $5 \mu \mathrm{m}$ thick formalin-fixed and paraffin-embedded tissue sections showed a well-circumscribed but non-encapsulated tumor, consisting of solid sheets and nests of neoplastic epithelial cells embedded in a loose fibrovascular stroma (Figure 4a). Most cells showed plasmacytoid (hyaline) myoepithelial features, i.e. abundant eosinophilic neoplasm and an oval, slightly dense, eccentric nucleus (Figure $4 \mathrm{~b})$. Small groups of spindle-shaped cells with dense nuclei were also observed (Figure 4c). There was a minimal cellular and nuclear pleomorphism and there were no atypical mitoses. Rare ductal structures were seen, but constituted $<2 \%$ of the total tumor parenchyma, while acinar differentiation was absent. Hemorrhage, inflammation and pseudoepitheliomatous hyperplasia of the covering parakeratinized mucosa were seen in the site of the incisional biopsy.

Immunohistochemistry was performed with a standard avidin-biotin peroxidase technique after pretreatment with high temperature citrate buffer, with antibodies against S-100 protein (polyclonal, 1:100, Dako, Glostrup, Denmark), cytokeratin (CK AE1/AE3, 1:50, Dako), glial fibrillary acidic protein (GFAP, 6F2, 1:100. Dako), calponin (CALP, 1Q50, Dako), a-SMA (HHF-35, 1:50, Dako), p63 (VS38c, 1:100, Dako), CD138/Syndecan-1 (B-A38, 1:50, Abcam, Cambridge, MA, USA), and Ki-67 (Mib1, 1:500, Dako). Plasmacytoid and spindle cells showed intense cytoplasmic positivity for S-100 protein (Figure 5a), and plasmacytoid cells diffuse cytoplasmic positivity for CK AE1/AE3, GFAP (Figure 5b), and calponin, scant cytoplasmic positivity for a-SMA and p63, and strong, membranous positivity for CD138/Syndecan-1 (Figure 5c). Ki-67 proliferation index was $<1 \%$. The diagnosis was plasmacytoid myoepithelioma.

\section{Discussion}

The case presented herein showed clinical, microscopic and immunohistochemical features consistent with plasmacytoid myoepithelioma. Panoramic radiograph and dental scan found no sign of erosion of the adjacent bone that, however, may be seen in benign salivary gland tumors, including plasmacytoid myoepithelioma (7). Microscopically, differentiation from a common pleomorphic adenoma was based on limited ductal differentiation that in our case was $<2 \%$, lack of chondroid or osteoid stroma, and predominance of myoepithelial cells $(1,4)$. 
mioepitelnih stanica $(1,4)$. U slučaju mioepitelioma, imunofenotip neoplastičnih stanica može se razlikovati među tumorima $(1,2,5)$ i različitim tipovima stanica unutar istog tumora $(1,2,5)$. U našem slučaju su plazmacitoidne i vretenaste stanice bile pozitivne na S-100, a plazmacitoidne su pokazivale i difuznu citoplazmatsku pozitivnost na CK AE1/AE3, GFAP i kalponin. Ta su protutijela u slučaju plazmacitoidnog mioepitelioma konstantan nalaz $(6,14)$, a pozitivna reakcija na SMA i GFAP može varirati $(6,7,14)$. U našem slučaju je $\alpha$-SMA bila jako ograničena, a GFAP je bio difuzan. Ako stanice pokažu da su pozitivne na GFAP, to bi moglo olakšati razlikovanje od mioepiteloidnog karcinoma jer su neoplastične mioepitelne stanice pleomorfnog adenoma pozitivne, a one pleomorfne s niskim stupnjem adenokarcinoma su GFAP negativne (11). U našem slučaju uočen je ograničeni p63 koji se inače pojavljuje u slučaju nekih mioepitelioma (15) i žljezdanih mioepitelnih karcinoma $(16,17)$. Zato bi se i dalje trebalo proučavati razlikovanje plazmacitoma i njegovih malignih oblika.

CD138/sindekan-1 uočen je u normalnim i neoplastičnim plazmatskim stanicama, te neoplastičnim stanicama s plazmacitoidnim obilježjima (18). Snažna pozitivna reakcija na membrani na CD138/sindekan-1 uočena je i u našem slučaju, a opisana je u još jednom slučaju plazmacitoidnog mioepitelioma (18). Manjak citoloških netipičnosti, stanični pleomorfizam, nekroza, krvarenje, infiltracija u okolno tkivo i nizak stupanj mitoze istaknuti su indeksom označavanja Ki 67 manjim od jedan posto, što je isključilo dijagnozu malignog mioepitelioma $(1,2,10)$.

Potpuna ekscizija tumora s čistim granicama obično je dovoljna za uspješnu terapiju (2), premda je opisano da su mioepiteliomi agresivniji od pleomorfnih adenoma (10). Ponovna pojava povezana je s pozitivnim rubovima i može nastati u slučaju mioepitelioma malih žlijezda slinovnica, posebno na nepcu gdje se tumor rijetko učahuri (1). Stopa ponovne pojave plazmacitoidnog mioepitelioma na nepcu procjenjuje se na 15 do 18 posto $(6,14)$. Maligna transformacija može se dogoditi, a posebno u vretenastim stanicama (12).

\section{Zaključak}

Budući da je plazmacitoidni mioepiteliom neuobičajen tumor malih žlijezda slinovnica, njegova imunohistokemijska obilježja, terapija i prognoza trebali bi se dalje istraživati, dobiveni rezultati dokumentirati i objavljivati.

\section{Sukob interesa}

Autori izjavljuju da nisu u bili u sukobu interesa.
The immunophenotype of neoplastic cells in myoepitheliomas may vary among different tumors $(1,2,5)$ and among different cell types of the same tumor $(1,2,5)$. In our case, both plasmacytoid and spindle cells were S-100 positive, and plasmacytoid cells, unlike spindle cells, showed diffuse cytoplasmic positivity for CK AE1/AE3, GFAP, and calponin. Expression of those antibodies in plasmacytoid myoepithelioma is a constant finding $(6,14)$, while SMA and GFAP positivity may vary $(6,7,14)$. In our case, $\alpha$-SMA expression was very limited, but GFAP expression was diffuse. GFAP expression could possibly facilitate differentiation from myoepithelial carcinoma, as neoplastic myoepithelial cells of pleomorphic adenoma are GFAP positive, but of polymorphous low-grade adenocarcinoma GFAP negative (11). Limited p63 expression was also seen in our case and p63 was found in some cutaneous myoepitheliomas (15) and salivary myoepithelial carcinomas $(16,17)$, therefore, its application in differentiation of plasmacytoma from its malignant variant should be further evaluated. CD138/Syndecan-1 is expressed by normal and neoplastic plasma cells, as well as neoplastic cells with plasmacytoid features (18). Strong, membranous positivity for CD138/Syndecan-1, as seen in the present case, was reported in a single case of plasmacytoid myoepithelioma (18). Lack of cytological atypia, cellular pleomorphism, necrosis, hemorrhage, infiltration into adjacent tissue, as well as low mitotic rate were highlighted by Ki-67 labeling index of $<1 \%$ and they precluded a diagnosis of malignant myoepithelioma $(1,2,10)$.

Complete surgical excision on tumor-free margins is usually curative (2), although myoepithelioma is reported to have more aggressive behavior to pleomorphic adenoma (10). Recurrence is associated with positive margins and this may occur in myoepitheliomas of minor salivary glands, especially of the palate, where tumor encapsulation is uncommon (1). Recurrence rate of plasmacytoid myoepitheliomas of the palate is estimated to $15-18 \%(6,14)$. Malignant transformation may ensue, particularly in the spindle cell variant (12).

\section{Conclusions}

Since plasmacytoid myoepithelioma is an uncommon tumor of minor salivary glands, its immunohistochemical features, management and prognosis should be further investigated through the publication of more documented cases.

\section{Conflict of Interest}

The authors report no conflicts of interest related to this study. 
Abstract

Background: Myoepitheliomas are uncommon salivary gland neoplasms consisting entirely or predominantly of cells with myoepithelial phenotype. They commonly involve the parotid gland and the minor salivary glands of the palate. Aim: A case of plasmacytoid myoepithelioma of the hard palate is described. Case description and results: A 55-year-old woman presented to her oral surgeon with a tumor on the hard palate. Microscopic examination showed a well-circumscribed but non-encapsulated tumor, consisting mostly of plasmacytoid cells in a loose fibrovascular stroma. Neoplastic myoepithelial cells showed immunoreactivity for S-100 protein, CK AE1/AE3 (Figure 5b), GFAP, calponin, and CD138/Syndecan-1. Total excision of the tumor under local anesthesia was performed and no recurrence was noted 14 months after treatment. Conclusions: Since plasmacytoid myoepithelioma is uncommon, minor salivary glands, its immunohistochemical features, management and prognosis should be further investigated.
Received: March 27, 2016

Accepted: March 6, 2017

Address for correspondence Christina Efthymia Souliou

University of Athens

School of Dentistry

Department of Oral Medicine and

Pathology

2 Thivon Street, Goudi

11527 Athens, Greece

Key words

Salivary Gland Neoplasms; Myoepithelioma; Pleomorphic Adenoma; hard Palate

\section{References}

1. Gnepp DR. Diagnostic Surgical Pathology of the Head and Neck. 2nd ed. Philadelphia: Saunders; 2001.

2. Hunt KT, Stevens MR, Abdelsayed RA, Nguyen CT. Benign myoepithelioma of floor of mouth with mandibular involvement: a case report and literature review. J Oral Maxillofac Surg. 2011 Dec;69(12):3001-5.

3. Ellis AL, Auclair PL. Benign epithelial neoplasms. 3rd ed. Washington, DC: Armed Forces Institute of Pathology; 1996.

4. Barnes L, Appel BN, Perez H, El-Attar AM. Myoepithelioma of the head and neck: case report and review. J Surg Oncol. 1985 Jan;28(1):21-8.

5. Savera AT, Zarbo RJ. Defining the role of myoepithelium in salivary gland neoplasia. Adv Anat Pathol. 2004 Mar;11(2):69-85.

6. Zormpa MT, Sarigelou AS, Eleftheriou AN, Assimaki AS, Kolokotronis AE. Plasmacytoid myoepithelioma of the palate: case report. Head Neck Pathol. 2011 Jun;5(2):154-8. 3098329.

7. Santos EP, Cavalcante DR, Melo AU, Pereira JC, Gomes MZ, Albuquerque RL Jr. Plasmacytoid myoepithelioma of minor salivary glands: report of case with emphasis in the immunohistochemical findings. Head Face Med. 2011 Dec 12;7:24.

8. Sethi D, Ahluvalia C, Khatri A, Khetarpal S. Palatal plasmacytoid myoepithelioma. Adv Biomed Res. 2012;1:78.

9. Kulkarni PR, Javalgi AP, Pottipati B, Shajahan F4. Plasmacytoid Myoepithelioma of the Hard Palate in a Child - A Rare Case Report. J Clin Diagn Res. 2015 Oct;9(10):ED01-2.

10. Yang S, Li L, Zeng M, Zhu X, Zhang J, Chen X. Myoepithelial carcinoma of intraoral minor salivary glands: a clinicopathological study of 7 cases and review of the literature. Oral Surg Oral Med Oral Pathol Oral Radiol Endod. 2010 Jul;110(1):85-93.
11. Curran AE, Allen CM, Beck FM, Damm DD, Murrah VA. Distinctive pattern of glial fibrillary acidic protein immunoreactivity useful in distinguishing fragmented pleomorphic adenoma, canalicular adenoma and polymorphous low grade adenocarcinoma of minor salivary glands. Head Neck Pathol. Head Neck Pathol. 2007 Sep;1(1):27-32.

12. Alos L, Cardesa A, Bombi JA, Mallofre C, Cuchi A, Traserra J. Myoepithelial tumors of salivary glands: a clinicopathologic, immuno histochemical, ultrastructural, and flow-cytometric study. Semin Diagn Pathol. 1996 May;13(2):138-47.

13. Gore CR, Panicker NK, Chandanwale SS, Singh BK. Myoepithelioma of minor salivary glands- A diagnostic challenge: Report of three cases with varied histomorphology. J Oral Maxillofac Pathol. 2013 May;17(2):257-60.

14. Kulkarni PR, Javalgi AP, Pottipati B, Shajahan F. Plasmacytoid Myoepithelioma of the Hard Palate in a Child - A Rare Case Report. J Clin Diagn Res. 2015 Oct;9(10):ED01-2.

15. Hornick JL, Fletcher CD. Cutaneous myoepithelioma: a clinicopathologic and immunohistochemical study of 14 cases. Hum Pathol. 2004 Jan;35(1):14-24.

16. Kane SV, Bagwan IN. Myoepithelial carcinoma of the salivary glands: a clinicopathologic study of 51 cases in a tertiary cancer center. Arch Otolaryngol Head Neck Surg. 2010 Jul;136(7):702 12.

17. Wang C, Zhang Z, Ge Y, Liu Z, Sun J, Gao Z, et al. Myoepithelial Carcinoma of the Salivary Glands: A Clinicopathologic Study of 29 Patients. J Oral Maxillofac Surg. 2015 Oct;73(10):1938-45.

18. Fionnuala P. CD138 (Syndecan-1), a Plasma Cell Marker Immunohistochemical Profile in Hematopoietic and Nonhematopoietic Neoplasms Hematopathology J Clin Pathol. 2004;121:254-263. 